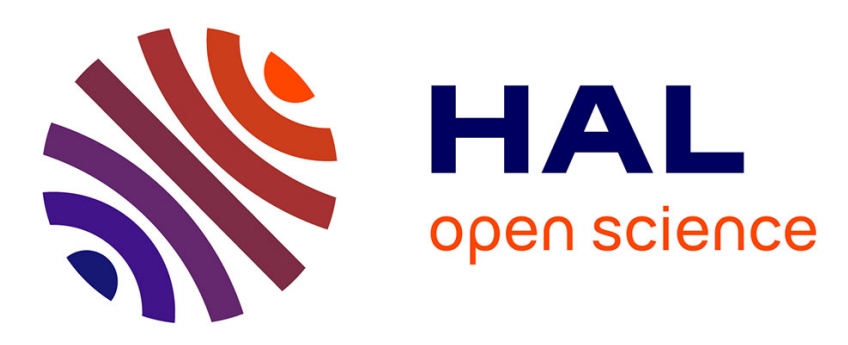

\title{
Pharmacokinetics, pharmacodynamics, metabolism, toxicology and residues of phenylbutazone in humans and horses.
}

\author{
Peter Lees, Pierre-Louis Toutain
}

\section{- To cite this version:}

Peter Lees, Pierre-Louis Toutain. Pharmacokinetics, pharmacodynamics, metabolism, toxicology and residues of phenylbutazone in humans and horses.. Veterinary Journal, 2013, 196 (3), pp.294-303. 10.1016/j.tvjl.2013.04.019 . hal-02648884

\section{HAL Id: hal-02648884 \\ https://hal.inrae.fr/hal-02648884}

Submitted on 29 May 2020

HAL is a multi-disciplinary open access archive for the deposit and dissemination of scientific research documents, whether they are published or not. The documents may come from teaching and research institutions in France or abroad, or from public or private research centers.
L'archive ouverte pluridisciplinaire HAL, est destinée au dépôt et à la diffusion de documents scientifiques de niveau recherche, publiés ou non, émanant des établissements d'enseignement et de recherche français ou étrangers, des laboratoires publics ou privés. 
Review

\title{
Pharmacokinetics, pharmacodynamics, metabolism, toxicology and residues of phenylbutazone in humans and horses
}

\author{
Peter Lees ${ }^{\mathrm{a}}$, Pierre-Louis Toutain ${ }^{\mathrm{b}, *}$ \\ ${ }^{a}$ Royal Veterinary College, Hawkshead Campus, Hatfield, Hertfordshire AL9 7TA, UK \\ b École National Vétérinaire de Toulouse, UMR 1331 Toxalim INRA, 23 Chemin des Capelles-BP 87614, 31076 Toulouse Cedex 03, France
}

\section{A R T I C L E I N F O}

Article history:

Accepted 28 April 2013

\section{Keywords:}

Equine

Human

Phenylbutazone

Oxyphenbutazone

Pharmacology

Toxicology

Residues

\begin{abstract}
A B S T R A C T
The presence of horse meat in food products destined for human consumption and labelled as beef has raised several concerns of public interest. This review deals solely with one aspect of these concerns; samples of equine tissue from horses destined for the human food chain have tested positive for the non-steroidal anti-inflammatory drug, phenylbutazone. The safety of some or all such foods for human consumers is a major concern, because it was shown many years ago that phenylbutazone therapy in humans can be associated with life threatening blood dyscrasias.

As an initial basis for assessing the potential toxicity of foods containing phenylbutazone and its metabolites, this article reviews (1) the pharmacokinetic, pharmacodynamic, metabolic and toxicological profiles of phenylbutazone, with particular reference to horses and humans; (2) toxicity data in laboratory animals; (3) phenylbutazone residues in food producing species, and (4) as a preliminary assessment, the potential hazard associated with the consumption of horse meat containing phenylbutazone and its metabolites.

Since phenylbutazone cannot be classified as a carcinogenic substance in humans, and noting that blood dyscrasias in humans are likely to be dose and treatment duration-dependent, the illegal and erratic presence of trace amount residues of phenylbutazone in horse meat is not a public health issue.
\end{abstract}

(c) 2013 Elsevier Ltd. All rights reserved.

\section{Introduction}

The presence of horse meat in burgers and other meat products labelled as beef and destined for human consumption is of major concern on several counts. One aspect of interest to the public and regulatory authorities is the detection of phenylbutazone in a very small percentage of carcasses destined for human consumption. This review provides an update on current knowledge of the pharmacological, toxicological and residue depletion profiles of phenylbutazone, with particular reference to published data in horses, humans and laboratory animals, as a relevant background to assessing the safety for consumers of foods containing phenylbutazone and its metabolites. The review does not seek to provide a full quantitative risk analysis. This will become possible when further data on the incidence and quantitative levels of phenylbutazone and its metabolites become available from on-going studies. Mutagenicity, genotoxicity and carcinogenicity of phenylbutazone are reviewed principally on the basis of cell culture and laboratory animal studies. An indication is given when the data are limited in scope or interpretation is equivocal.

\footnotetext{
* Corresponding author. Tel.: +33 561193912.

E-mail address: pltoutain@wanadoo.fr (P.-L. Toutain).
}

Phenylbutazone has brought major welfare benefits to horses as an analgesic/anti-inflammatory agent over more than 50 years of clinical use. At the same time, its availability has become so extensive in many countries that proper control of its use, to ensure that horses treated with the drug do not enter the human food chain, poses a significant challenge, which can and must be met. It is a low cost drug available in granule, paste and injectable formulations for equine use, but is not available for use in any other food producing species. It was formerly available in oral formulations for human use.

This review makes no attempt to undertake a full risk analysis relating to the presence of phenylbutazone in low concentrations in horse or processed meat samples destined for human consumption. This will be appropriate, when further residues data become available from surveillance to form the basis of a quantitative risk evaluation.

\section{History of phenylbutazone use}

Phenylbutazone was introduced into human medicine in 1949 as a novel agent of the non-steroidal anti-inflammatory drug (NSAID) class for use in the treatment of acute and chronic inflammatory pain, notably various forms of arthritis (Von Rechenberg, 1962). It proved to be an excellent analgesic and, for $\sim 30$ years, 
was used extensively, for example, as the drug of choice for treatment of arthritides. The phenylbutazone pioneer product, Butacote, was licensed originally to Geigy Pharmaceuticals and subsequently to Novartis Pharmaceuticals. The manufacturers' recommended dosage was: (1) Adults: For the initial $48 \mathrm{~h}, 400$ $600 \mathrm{mg}$ daily in divided doses; thereafter, reduce to the minimum amount necessary, usually 200-300 mg in divided doses; at the time of its introduction in 1949, a higher dose of $1 \mathrm{~g}$ per subject per day was used; and (2) Elderly subjects: Always use the minimum effective dose.

In the 1980 s, severe restrictions were placed on phenylbutazone use in humans. The later history of this product was briefly as follows: (1) 1984: the $200 \mathrm{mg}$ tablets were discontinued for commercial reasons; (2) May 1984: the product licence was restricted to the treatment of ankylosing spondylitis, for hospital use only; and (3) September 2002: the $100 \mathrm{mg}$ tablets were withdrawn from the market for commercial reasons. Peak use in the USA was in 1974, when 14 million prescriptions were issued and this decreased to 2 million in 1984. In that year the safety of phenylbutazone was examined by a USA Food and Drugs Administration (FDA) advisory committee (Faich, 1987).

Curtailment of the use of phenylbutazone in the 1980s resulted from the recognition that it induces, very rarely, blood dyscrasias, including aplastic anaemia, leukopenia, agranulocytosis and thrombocytopenia, in some cases leading to death. Hypersensitivity reactions of the serum sickness type were also reported. Fatalities were associated with use in humans at manufacturers' recommended dose rates. Nevertheless, therapeutic use was still allowed in individual patients, under specialist control and with regular blood profile monitoring. Thus, in some countries, phenylbutazone licensed to generic companies has continued to be used.

Phenylbutazone was introduced into veterinary medicine in the 1950s, and has now been used, to a limited degree, in the dog and, very extensively, in the horse for $>50$ years. In equine medicine, it has continued to dominate the treatment of pain, particularly that associated with joint and muscle conditions. Advantages for equine medicine include extensive clinical experience of efficacy and safety over both short and long treatment periods, and availability in parenteral and a range of oral (powder, paste and bolus) formulations.

\section{Chemistry and physicochemical properties of phenylbutazone}

Phenylbutazone (molecular weight $308.37 \mathrm{~g} / \mathrm{mol}$ ) is a lipophilic substance (XLogP3: 3.2); solubility in water is sparing $(0.7 \mathrm{mg} / \mathrm{mL})$, but the sodium salt is freely soluble. Phenylbutazone is unstable on storage, both as dry powder (Awang et al., 1973) and in solution (Schmid, 1970; Bellward et al., 1972). For example, exposure to air during thin layer chromatography caused significant spontaneous breakdown of both phenylbutazone and its metabolites (Bakke et al., 1974). It is therefore important to use freshly prepared solutions of phenylbutazone in the preparation of standards for analytical methods.

Studies in equine fluids demonstrated chemical breakdown of phenylbutazone (Taylor et al., 1981). Degradation occurred at $4{ }^{\circ} \mathrm{C}$ over $8-10$ weeks storage in plasma ( $\sim 50 \%$ loss) and urine (>95\% loss). The stability of phenylbutazone in meat before and after cooking is unknown.

\section{Pharmacology and therapeutics}

Pharmacokinetics of phenylbutazone in the horse

In the UK, phenylbutazone is available in products for parenteral (for IV use only) and oral dosing in the horse. In France, phenylbutazone is available only for oral administration and for a single indication, chronic laminitis. The early literature is extensive and has been summarised in several reviews (Gabel et al., 1977; Lees and Higgins, 1985; Tobin et al., 1986; Lees et al., 2004; Soma et al., 2011). After IV dosing, clearance and elimination half-life are of the order of $16-26 \mathrm{~mL} / \mathrm{h} / \mathrm{kg}$ and $4-6 \mathrm{~h}$, respectively (Lees and Higgins, 1985; Lees et al., 1986a; Maitho et al., 1986). Phenylbutazone is well absorbed after oral dosing as granules, paste or bolus formulations. Several metabolites have been identified; the principal ones are oxyphenbutazone and $\gamma$-hydroxyphenylbutazone. These two metabolites are of particular interest, since they possess analgesic/anti-inflammatory properties and thus contribute (to an unknown but probably small/moderate degree) to the pharmacological actions of phenylbutazone. For both metabolites, urine concentrations are much higher than those in plasma.

The bioavailability of phenylbutazone is in the range of 69-91\% (Chay et al., 1984; Lees and Higgins, 1985, 1986; Maitho et al., 1986; Smith et al., 1987; Delbeke et al., 1993). These and several other studies demonstrate that the rate of absorption varies considerably between and within horses and also according to whether the horse has free access to feed (grass, hay, pelleted feed) at the time of oral dosing (Gerring et al., 1981; Maitho et al., 1986). If feed is withheld for 3-4 h both before and after dosing, the maximum concentration in plasma (Cmax) occurs (Tmax) at $\sim 4-6 \mathrm{~h}$ and is usually characterised by a single peak. If, on the other hand, the horse has full access to feed at the time of oral dosing, there is usually a very small initial peak in plasma concentration after 1$2 \mathrm{~h}$, then a return to baseline, followed by a much larger secondary absorption phase from 10 to $24 \mathrm{~h}$, giving a mean Tmax of $12-14 \mathrm{~h}$ (Maitho et al., 1986). The difference between the two absorption profiles (fed vs. non-fed) has been ascribed to adsorption of phenylbutazone onto the fibrous component of hay/grass/nuts, rendering the adsorbed fraction unavailable for absorption until the drug is released by fermentative digestion in the large intestine (Lees and Higgins, 1986; Lees et al., 1988).

The binding of phenylbutazone to plasma proteins (principally albumin) in the horse (and in all species investigated) is of the order of $\geqslant 98 \%$. Consequently, its distribution from plasma to interstitial and transcellular fluids, such as peritoneal fluid, is limited, the distribution volume being very small, $\sim 0.1-0.3 \mathrm{~L} / \mathrm{kg}$ (Lees et al., 1986b). Despite this limited general distribution, phenylbutazone is distributed well to sites of acute inflammation, probably as a consequence of two factors: (1) increased blood flow; (2) increased capillary and small vein permeability, leading to leakage of plasma proteins, with their bound phenylbutazone attached, into the inflammatory exudate (Lees and Higgins, 1986).

The distribution of drugs extensively bound to plasma proteins in plasma, in extracellular fluids outside the plasma and in the remainder of the body can be predicted readily, taking into account the free fraction in plasma (fu) and the volume of distribution (Rowland and Tozer, 2009); for the horse, fu is 2\% and the volume of distribution is $\sim 0.17 \mathrm{~L} / \mathrm{kg}$. Therefore, it is predicted that $29.4 \%$ of phenylbutazone in the body will be located in plasma and $45.5 \%$ in extracellular fluid outside the plasma, with only $25 \%$ being present in the remainder of the body. This indicates that high total tissue concentrations of phenylbutazone will not occur and this is consistent with experimental data (vide infra).

Due to the high degree of plasma protein binding, the ultrafiltration of phenylbutazone through glomerular capillaries into Bowman's capsule fluid is limited to no more than $1-2 \%$ of total plasma concentration. The contribution of renal clearance to phenylbutazone elimination was shown to be similar at rest and under test exercise conditions ( $11.2 \%$ and $12.9 \%$, respectively, $P>0.05$ ) (Authié et al., 2010). Of the small fraction of total concentration filtered, some is subsequently reabsorbed, since phenylbutazone is lipophilic. Consequently, in the horse, the urine:plasma 
concentration ratio is low, $\sim 2: 1$ (Gerring et al., 1981; Lees et al., 1988). The elimination of phenylbutazone is dependent principally on hepatic metabolism. Hepatic clearance is significantly decreased $(-25.3 \%, P=0.02)$ in test exercise conditions (Authié et al., 2010).

\section{Pharmacokinetics of phenylbutazone in other veterinary species}

There are marked species differences in the clearance and elimination half-life of phenylbutazone (Table 1 ), whereas volume of distribution is systematically low $(0.1-0.3 \mathrm{~L} / \mathrm{kg})$ in all species investigated.

\section{Pharmacokinetics of phenylbutazone in humans}

The pharmacokinetic profile of phenylbutazone in humans is characterised by a very slow clearance, extensive metabolism, long terminal half-life and a very high degree of binding (98-99\%) to plasma proteins, principally albumin. Absorption is almost complete after oral dosing. After a typical dose of $300 \mathrm{mg}$, a Cmax of the order of $35-50 \mu \mathrm{g} / \mathrm{mL}$ is obtained within $3 \mathrm{~h}$. However, after repeat daily dosing at steady state, achieved after several days, average plasma concentrations are $\sim 95 \mu \mathrm{g} / \mathrm{mL}$ for phenylbutazone and $45 \mu \mathrm{g} / \mathrm{mL}$ for its metabolite oxyphenbutazone. Only $1 \%$ of the administered dose is excreted in urine as the parent drug, while most (up to $72 \%$ ) is excreted in urine as metabolites and $10 \%$ is excreted in bile also as metabolites. Of the several identified metabolites, oxyphenbutazone and $\gamma$-hydroxyphenylbutazone have been described as pharmacologically active and they predominate over other metabolites in plasma (Burns et al., 1953; Yu et al., 1958; Bakke et al., 1974; Dieterle et al., 1976; Aarbakke et al., 1977; Triggs et al., 1977; Aarbakke, 1978). Whittaker and Price Evans (1970) demonstrated that phenylbutazone metabolism is under polygenic control and influenced by the environment. Phenylbutazone clearance may be dose dependent (Davies and Thorgeirsson, 1971; Horwitz et al., 1977). As for all species investigated, the volume of distribution of phenylbutazone is low $(\sim 10 \mathrm{~L} ; 0.15 \mathrm{~mL} / \mathrm{kg}$ for a bodyweight of $70 \mathrm{~kg}$ in humans).

From several studies, the mean elimination half-life of phenylbutazone using specific methods is usually in the range of 50$105 \mathrm{~h}$, but large intra- and inter-individual variation has been reported. A skewed distribution of elimination half-life has been demonstrated ( $n=155$ subjects; median $79 \mathrm{~h}$, range $50-300 \mathrm{~h}$ ) (Aarbakke et al., 1977).

As a consequence of the slower clearance of phenylbutazone in humans compared to horses (bioavailabilities are of a similar order) the area under the plasma concentration time curve after oral

Table 1

Species differences in clearance and elimination half-life of phenylbutazone. ${ }^{a}$

\begin{tabular}{lll}
\hline Species & Clearance $(\mathrm{mL} / \mathrm{h} / \mathrm{kg})$ & Elimination half-life $(\mathrm{h})$ \\
\hline Calf (neonatal) & 0.708 & 207 \\
Human & About 2 & $50-105$ \\
Cow & $1.24-2.90$ & $42-65$ \\
Sheep & - & 18 \\
Goat & 13 & 16 \\
Camel & $4.9-10.0$ & 13 \\
Baboon & - & 5 \\
Horse & $16.3-26.0$ & $4.0-6.0$ \\
Dog & 18.4 & $2.0-6.0$ \\
Guinea pig & - & 5 \\
Rat & $35-83$ & $2.8-5.4$ \\
Pig & 39 & 1.83 \\
Rabbit & 65 & 1.89 \\
Donkey & 170 & $1.0-2.0$
\end{tabular}

\footnotetext{
a Data from various publications (summarised in Lees et al. (2004)).
}

dosing with similar dose rates $(4-5 \mathrm{mg} / \mathrm{kg}$ ) is proportional to the difference between plasma clearance, i.e. $\sim 25$ times greater in humans than horses.

\section{Depletion of phenylbutazone residues}

There are only limited published data on tissue concentrations and residue depletion profiles of phenylbutazone. In an equine study (one horse per time point), plasma concentrations of phenylbutazone and oxyphenbutazone exceeded tissue (muscle, liver and kidney) concentrations at slaughter times of 6,12 and $24 \mathrm{~h}$. Biceps and gluteal muscle concentrations were particularly low, so that plasma:muscle concentration ratios ranged from 25:1 to 64:1 (Table 2; Lees et al., 1987). Phenylbutazone (and oxyphenbutazone) concentrations at $24 \mathrm{~h}$ were $0.6(0.2) \mu \mathrm{g} / \mathrm{mL}$ in plasma and $<0.1$ $(<0.1) \mu \mathrm{g} / \mathrm{g}$ in both the biceps and gluteal muscles.

These limited equine data are confirmed by plasma:loin muscle concentration ratios of phenylbutazone in rabbits of 16:1-33:1 at seven slaughter times after a dosage of $8 \mathrm{mg} / \mathrm{kg}$ (Toutain et al., 1980b). Phenylbutazone concentrations in liver and kidney in the rabbit were lower than corresponding plasma concentrations, but higher than corresponding muscle concentrations. Similarly, in cattle plasma:muscle concentration ratios of phenylbutazone ranged from $8: 1$ to $21: 1$. In addition, there was good parallelism between the decay of plasma phenylbutazone concentrations and decreases in phenylbutazone concentrations in muscle and liver, indicating that plasma concentrations provide a good marker of tissue concentrations; however, in this species, absolute concentrations were much higher than in horses after administration of a dose rate of $7.5 \mathrm{mg} / \mathrm{kg}$ (Toutain et al., 1980a). The plasma:muscle ratio was 9.7:1 in dogs (Dayton et al., 1973). These data indicate that, in four species, muscle concentrations are systematically lower than plasma concentrations by at least one order of magnitude (i.e. a factor of 10$)$.

After IV administration of phenylbutazone at a dose rate of $8.8 \mathrm{mg} / \mathrm{kg}$, average plasma concentrations in four horses at 24 , 48,72 and $96 \mathrm{~h}$ post-administration were $1.24,0.16,0.06$ and $0.03 \mu \mathrm{g} / \mathrm{mL}$, respectively (Orszag, 2008). Assuming a plasma:muscle ratio of $10: 1$, the predicted muscle concentrations would be $120,16,5.7$ and $2.4 \mu \mathrm{g} / \mathrm{kg}$, respectively.

\section{Pharmacodynamics and therapeutic indications}

At the whole animal level, phenylbutazone possesses the classical trio of properties, which characterise NSAIDs: analgesic, antiinflammatory and antipyretic (Lees and Higgins, 1985; Toutain et al., 1994). Using a pharmacokinetic/pharmacodynamic (PK/PD) modelling approach, the effective plasma concentrations were estimated to range from 1 to $4 \mu \mathrm{g} / \mathrm{mL}$ (Toutain et al., 1994). The analgesic action is well demonstrated for inflammatory pain. At the molecular level, the principal mechanism of action of NSAIDs, for both pharmacological and toxic effects, is inhibition of cyclooxygenase (COX) (Vane, 1971; Lees and Higgins, 1985; Lees et al., 2004). COX exists in two isoforms, COX-1 and COX-2 (Kujubu et al., 1991; Lees et al., 2004). COX-2 is the isoform which generates pro-inflammatory prostaglandins (PG), e.g. PGE $_{2}$ at sites of tissue damage. Its local inhibition (and also inhibition at central sites) explains the suppression of inflammatory pain and oedema.

In the horse, at the clinically recommended dose rate $(4.4 \mathrm{mg} /$ $\mathrm{kg}$ ) phenylbutazone produced $70-100 \%$ inhibition of $\mathrm{PGE}_{2}$ up to $24 \mathrm{~h}$ in exudate in a model of acute inflammation, indicating a marked and persistent inhibition of COX-2 (Higgins et al., 1984). It also inhibited serum thromboxane $B_{2}$ synthesis by $50-100 \%$ for up to $24 \mathrm{~h}$, indicating marked and persistent inhibition of COX-1 as well (Lees and Higgins, 1987). Therefore, phenylbutazone may be classified as a non-selective inhibitor of the two COX isoforms, 
Table 2

Concentrations of phenylbutazone and oxyphenbutazone in equine fluids and tissues after administration of phenylbutazone at a dose rate of 4.4 mg/kg.

\begin{tabular}{|c|c|c|c|c|c|c|}
\hline Horse & $\begin{array}{l}\text { Route of } \\
\text { administration }\end{array}$ & $\begin{array}{l}\text { Time } \\
\text { after } \\
\text { dosing (h) }\end{array}$ & $\begin{array}{l}\text { Fluid/ } \\
\text { tissue }\end{array}$ & $\begin{array}{l}\text { Phenylbutazone } \\
\text { concentration } \\
(\mu \mathrm{g} / \mathrm{mL} \text { or } \mu \mathrm{g} / \mathrm{g})\end{array}$ & $\begin{array}{l}\text { Oxyphenbutazone } \\
\text { concentration } \\
(\mu \mathrm{g} / \mathrm{mL} \text { or } \mu \mathrm{g} / \mathrm{g})\end{array}$ & $\begin{array}{l}\text { Phenylbutazone } \\
\text { plasma:tissue } \\
\text { concentration } \\
\text { ratio }\end{array}$ \\
\hline 1 & Intravenous & 6 & $\begin{array}{l}\text { Plasma } \\
\text { Biceps muscle } \\
\text { Gluteal muscle } \\
\text { Liver } \\
\text { Kidney } \\
\text { (cortex) }\end{array}$ & $\begin{array}{r}12.3 \\
0.5 \\
0.3 \\
1.5 \\
2.1\end{array}$ & $\begin{array}{l}2.6 \\
0.1 \\
0.1 \\
0.3 \\
1.8\end{array}$ & $\begin{array}{l}- \\
25: 1 \\
41: 1 \\
8: 1 \\
6: 1\end{array}$ \\
\hline 2 & Oral & 6 & $\begin{array}{l}\text { Plasma } \\
\text { Biceps muscle } \\
\text { Gluteal muscle } \\
\text { Liver } \\
\text { Kidney } \\
\text { (cortex) }\end{array}$ & $\begin{array}{l}3.3 \\
0.1 \\
0.1 \\
0.7 \\
0.7\end{array}$ & $\begin{array}{l}1.1 \\
0.1 \\
0.1 \\
0.2 \\
1.1\end{array}$ & $\begin{array}{l}- \\
33: 1 \\
33: 1 \\
5: 1 \\
5: 1\end{array}$ \\
\hline 3 & Oral & 12 & $\begin{array}{l}\text { Plasma } \\
\text { Biceps muscle } \\
\text { Gluteal muscle } \\
\text { Liver } \\
\text { Kidney } \\
\text { (cortex) }\end{array}$ & $\begin{array}{l}6.4 \\
0.2 \\
0.1 \\
0.2 \\
2.4\end{array}$ & $\begin{array}{r}1.1 \\
0.1 \\
0.1 \\
<0.1 \\
1.0\end{array}$ & $\begin{array}{l}- \\
32: 1 \\
64: 1 \\
32: 1 \\
3: 1\end{array}$ \\
\hline
\end{tabular}

a Data from Lees et al. (1987).

this non-selective action being confirmed by Brideau et al. (2001) in in vitro whole blood assays. Quantitative data on phenylbutazone COX inhibition in humans is limited, but, somewhat surprisingly, Gierse et al. (2002) reported low potency; for both COX-1 and COX-2 isolated enzymes $50 \%$ inhibitory concentrations were $>500 \mu \mathrm{M}$.

\section{Toxicology}

General toxicity profile of phenylbutazone

The considerable evidence in the clinical and scientific literature indicates that the most common, serious and severe sideeffects of NSAIDs, including phenylbutazone, relate to inhibition of COX-1. They include: (1) perforation, ulceration and bleeding (PUB) of the gastrointestinal tract, and (2) uncontrolled haemorrhage leading to internal or external bleeding. Since COX-2 is present constitutively in the kidney, some renal side-effects may be attributable to COX-2, as well as COX-1, inhibition.

\section{Toxicity of phenylbutazone in laboratory animals}

Acute toxicity data for phenylbutazone in laboratory animals, expressed as median (50\%) lethal dose (LD50), are presented in Table 3 for four species. Oral LD50 values were 2.5-5.3 times greater than corresponding intravenous values (Lewis, 2004). Chronic daily exposure to phenylbutazone has also been investigated. There was $70 \%$ mortality in rats dosed with $600 \mathrm{mg} / \mathrm{kg}$ phenylbutazone daily for 19 days and 30\% mortality with a dosage of $200 \mathrm{mg} / \mathrm{kg} /$ day for 13 weeks (Lewis, 2004). When fed to rats in drinking water for 4 months at a concentration of $0.25 \%$, there were no demonstrable effects on red or white cell counts (Hazleton et al., 1953). Likewise, there were no adverse haematological effects after incorporation of phenylbutazone in feed at a concentration of $0.5 \%$ over 90 days, although reduced food intake and body weight loss were reported (Hazleton et al., 1953). Incorporation in feed at $1 \%$ was not tolerated.

In dogs, dose rates of $10-100 \mathrm{mg} / \mathrm{dog} /$ day produced no apparent adverse effects, whereas deaths occurred within 12 weeks at
Table 3

Acute toxicity of phenylbutazone: median lethal doses. ${ }^{\mathrm{a}}$

\begin{tabular}{llc}
\hline Species & Route of administration & $\mathrm{LD}_{50}(\mathrm{mg} / \mathrm{kg})^{\mathrm{b}}$ \\
\hline Mouse & Intravenous & 90 \\
& Oral & 270 \\
& Intramuscular & 430 \\
Rat & Intravenous & 100 \\
& Oral & 245 \\
\multirow{3}{*}{ Rabbit } & Intramuscular & 220 \\
& Intravenous & 146 \\
Dog & Oral & 781 \\
& Intravenous & 121 \\
& Oral & 332 \\
\hline
\end{tabular}

\footnotetext{
a Data from Lewis (2004)
}

b Median (50\%) lethal dose.

$200 \mathrm{mg} / \mathrm{kg}$. At doses up to $100 \mathrm{mg} / \mathrm{dog} / \mathrm{day}$, blood counts and bone pathology were normal (Hazleton et al., 1953).

\section{Toxicity of phenylbutazone in the horse}

Snow et al. (1979) reported that oral dose rates of phenylbutazone in the range $8.7-14.6 \mathrm{mg} / \mathrm{kg} /$ day for up to 14 days in pony breeds produced severe side-effects and some fatalities. At that time, the recommended dose rate of the manufacturer in the UK was $8.8 \mathrm{mg} / \mathrm{kg}$ for 4 days, followed by halving the dose for a further 4 days, then halving the dose rate again for longer term therapy. These horses were therefore overdosed and the toxicity was initially assumed to be related to pony breeds. However, several subsequent studies with phenylbutazone dose rates exceeding those recommended by the manufacturer confirmed the toxicity of phenylbutazone in both small and large equines (Snow et al., 1981; MacAllister, 1983; MacKay et al., 1983; Traub et al., 1983; Collins and Tyler, 1984; McConnico et al., 2008). For example, in horses, dose rates of $15-30 \mathrm{mg} / \mathrm{kg} /$ day IV led to death from 4 to 7 days, preceded by neutropenia, but with less marked decreases in neutrophil counts at $8 \mathrm{mg} / \mathrm{kg} /$ day for 2 weeks (MacKay et al., 1983).

Even when Thoroughbred and Hunter horses were dosed in our laboratory with the manufacturers' then recommended dose rates 
( $8.8 \mathrm{mg} / \mathrm{kg}$ for 4 days, then $4.4 \mathrm{mg} / \mathrm{kg}$ for 4 days, then $2.2 \mathrm{mg} / \mathrm{kg}$ thereafter), we reported toxicity, probably related to protein-losing enteropathy, but without fatalities (Lees et al., 1983). Therefore, the problem seemed to be one of daily dose rate rather than horse breed; this was confirmed by the lack of demonstrable toxicity with a dosage regimen of $8.8 \mathrm{mg} / \mathrm{kg}$ (loading dose on day 1 only), then $4.4 \mathrm{mg} / \mathrm{kg}$ for 4 days, then $2.2 \mathrm{mg} / \mathrm{kg}$ thereafter (Taylor et al., 1983). No toxicologically significant effects were obtained in a further study, involving the administration of phenylbutazone to horses orally with a daily maintenance dose of $3.3 \mathrm{mg} / \mathrm{kg}$ (Lees and Higgins, 1987).

It was further reported that other NSAIDs then available for equine use, including flunixin and meclofenamate, as well as the reported toxicity with high doses of phenylbutazone, were probably due to protein losing-enteropathy. However, decreases in plasma protein and albumin concentration did not occur with the lower dose rates of phenylbutazone. It was concluded that, whilst phenylbutazone has a steep dose response relationship for toxicity, it was shown to be clinically safe and effective when used at the now recommended dose rate, even when administered over prolonged periods. It is also of interest to note that suxibuzone, a pro-drug which is converted to phenylbutazone in vivo, has a wider safety margin than phenylbutazone in the horse (Jaraiz et al., 1999).

\section{Carcinogenicity of phenylbutazone}

The carcinogenicity and promoting effect of phenylbutazone were investigated in inbred DONRYU rats by Maekawa et al. (1987) at dietary incorporation levels of 0 (control), 0.125 or $0.25 \%$ for 2 years. Various tumours were detected in all groups, including the controls. With the exception of phaeochromocytoma in the female high-dose group, no statistically significant increase in yield of tumours, including leukaemia, was apparent in the treated groups of either sex when the data were analysed by Fisher's exact probability and/or $\chi^{2}$ tests. However, application of an age-adjusted statistical analysis revealed a slight positive effect regarding the occurrence of phaeochromocytomas, neoplastic liver nodules and leukaemias in females. These tumours commonly occur spontaneously in this rat strain and no such effect was apparent in the male groups. In addition, no differences in incidences of relevant pre-neoplastic lesions were evident between control and treated groups. The authors concluded that phenylbutazone exerted no carcinogenic activity in DONRYU rats when administered continually in the diet for 2 years. No enhancement of nitrosourea-induced leukaemogenesis was apparent, although a slight promoting effect was demonstrated for renal and thyroid tumorigenesis.

Kari et al. (1995) conducted 2 year rat studies, administering 0,50 or $100 \mathrm{mg} / \mathrm{kg}$ phenylbutazone by gavage to groups of 50 animals of each sex, 5 days per week for 103 weeks. In a murine study, doses given to groups of 50 mice of each sex also on a 5 day per week schedule were 0,150 or $300 \mathrm{mg} / \mathrm{kg}$. There was equivocal evidence of carcinogenic activity of phenylbutazone in male $\mathrm{F} 344 / \mathrm{N}$ rats, as shown by the occurrence of small numbers of renal tubular cell adenomas and carcinomas. There was also some evidence of carcinogenic activity for female F344/N rats, as shown primarily by the occurrence of two rare transitional cell carcinomas in the high dose group. Tubular cell adenomas may have been associated with the administration of phenylbutazone to female rats. There was some evidence of carcinogenic activity for male B6C3F1 mice, as shown by the increased combined incidence of hepatocellular adenomas or carcinomas. There was no evidence of carcinogenicity in female B6C3F1 mice administered phenylbutazone at daily doses of 150 or $300 \mathrm{mg} / \mathrm{kg}$ for 2 years.

\section{Studies of mutagenesis and genotoxicity}

For mutagenesis, Giri and Mukhopadhyay (1998) reported negative findings for phenylbutazone and oxyphenbutazone in an Ames test plate incorporation assay (concentrations up to $20 \mathrm{mg} /$ plate) using four strains of Salmonella. Mortelmans et al. (1986) had previously reported negative results in the Salmonella/microsome pre-incubation assay at concentrations up to $10 \mathrm{mg} /$ plate. Negative results were obtained for phenylbutazone in the dominant lethal test after administration intraperitoneally in mice at doses of 50 and $100 \mathrm{mg} / \mathrm{kg}$. Kirkland and Fowler (2010) noted that phenylbutazone is not predicted to be a mutagen by Computer Software analysis that simulates its interaction with DNA.

Several other reports of negative findings for phenylbutazone in genotoxicity/mutagenicity assays have been made. For example, there was no induction of chromosomal aberrations in bone marrow cells of mice, hamsters or rats administered phenylbutazone. However, Giri and Mukhopadhyay (1998) reported that phenylbutazone $(50,100$ and $200 \mathrm{mg} / \mathrm{kg})$ and oxyphenbutazone $(25,50$ and $100 \mathrm{mg} / \mathrm{kg}$ ) increased sister chromatid exchanges in vivo in bone marrow cells of male mice and both were therefore genotoxic in this test. Moreover, Stevenson et al. (1971) carried out chromosomal studies in 50 patients taking phenylbutazone (100$500 \mathrm{mg} /$ day) for at least 3 months compared with 31 controls. The frequency in the number of chromosome abnormalities resulting from chromosome breakage events in cultured peripheral leucocytes was significantly increased. Investigation of chromosomal damage in bone marrow cells yielded negative results. For an extensive review of publications relating to phenylbutazone mutagenesis, see phenylbutazone in the data base PubMed compound. ${ }^{1}$

\section{Toxicity in humans}

\section{Gastrointestinal tract}

Classical NSAIDs have been used on a massive scale for many years. Of low percentage but high absolute incidence are the PUBs of the upper gastrointestinal tract. An indication of the scale of these side-effects was provided by reports which estimated 107,000 hospitalisations and 16,500 deaths annually in the USA (Singh, 1998; Singh and Triadafilopoulos, 1999). These estimates related to gastrointestinal complications (notably peptic and duodenal ulcers) for arthritis patients alone. For further discussion see Appendix A (1).

\section{Cases of acute intoxication with phenylbutazone}

There are literature reports of phenylbutazone poisoning in humans associated with oral consumption of veterinary products. A 24 year old man ingested $17 \mathrm{~g}$ over a $24 \mathrm{~h}$ period (corresponding to an estimated dose of $\sim 200-250 \mathrm{mg} / \mathrm{kg}$ ) (Newton and Rose, 1991). He developed grand mal seizures, hypertension, respiratory and renal failure and liver damage. Eight hours after dosing, serum phenylbutazone concentrations were $900 \mu \mathrm{g} / \mathrm{mL}$, which is of the order of 20 and 100 fold higher than the concentrations achieved at steady state in humans and horses, respectively, with the recommended clinical dose rates. The patient recovered during 6 weeks of intensive supportive care and repeated haemodialysis. A second male subject, who received an unknown but high dose of equine phenylbutazone, had serum concentrations in the range 420$510 \mu \mathrm{g} / \mathrm{mL}$ for $2-16 \mathrm{~h}$ post ingestion (and oxyphenbutazone concentrations of $45-50 \mu \mathrm{g} / \mathrm{mL}$ ), and displayed similar toxicity (Liang

\footnotetext{
1 See: http://pubchem.ncbi.nlm.nih.gov/summary/summary.cgi?cid=4781andloc=ec_rcs\#x332 (accessed 8 April 2013).
} 
et al., 2004). He recovered fully after several weeks of intensive care.

\section{Blood dyscrasias: Clinical data}

In the period of early use after its introduction in 1949, the incidence of adverse haematological effects, with a phenylbutazone dose rate of $1 \mathrm{~g}$ per subject daily, was higher than subsequently (dosage of the order of 300-600 mg); in a study of 188 rheumatoid arthritis patients, 16\% developed thrombocytopenia and 10\% developed anaemia (Stephens et al., 1952). von Rechenberg (1962) reported 51 deaths and 38 non-fatal cases of agranulocytosis linked to phenylbutazone usage from an estimated population of 50 million treated humans.

In the early period of phenylbutazone usage (often with the higher dosage of $1 \mathrm{~g}$ per subject per day), fatal blood dyscrasias were reported in 133 humans, comprising an incidence of 1 in 20,000 treated patients per annum (Fowler, 1967). In this study, agranulocytosis was more common in younger subjects, arising after $\sim 3$ months, whilst aplastic anaemia was more common in the elderly, appearing after $\sim 12$ months of treatment in most subjects. In another early review of 12 deaths from blood dyscrasias associated with phenylbutazone usage, the cause of death was agranulocytosis in 10 cases (Mauer, 1955).

Other haematological adverse effects associated with phenylbutazone and oxyphenbutazone therapy in humans include leukopenia, pancytopenia, thrombocytopenia, haemorrhage and anaemia secondary to gastrointestinal bleeding, as well as (rarely) macrocytic or megaloblastic anaemia (Chaplin, 1986).

As well as a number of individual case histories (Hale and De Gruchy, 1960; Lander and Bonnin, 1962; McCarthy and Chalmers, 1964; Cameron et al., 1966), Ramsey and Golde (1976) summarised 10 earlier reports in which marrow depression was associated with use of phenylbutazone. These authors further reported that, in any given week in 1962, 100,000 humans in Great Britain were receiving phenylbutazone therapy. In addition, surveys indicated that deaths from aplastic anaemia occurred in the UK with an incidence of $\sim 1$ in 40,000-50,000 phenylbutazone treated patients (Chaplin, 1986).

Bottiger and Westerholm (1973) and Bottiger (1977) reported an incidence in Sweden of 1-3 cases per 100,000 for phenylbutazone and oxyphenbutazone combined. The incidence seems to be lower in humans aged $<65$ years, in whom therapeutic doses are administered daily over long periods. As Faich (1987) pointed out, risk estimates of the order of 3 per 100,000 treated subjects or less inevitably derive from epidemiological observations, and estimates are influenced by case selection, bias and confounding, so that confidence intervals are usually wide. Inman (1977) described 28 deaths which were probably attributable to phenylbutazone and 11 to oxyphenbutazone in 269 patients dying of aplastic anaemia. For the phenylbutazone treated patients, dosage ranged from 200 to $400 \mathrm{mg}$ for periods ranging from less than 1 month to 7 years. The overall death rate was 2.2 per 100,000 treated subjects, ranging from 1 in 100,000 for men aged less than 65 to 6 in 100,000 for women aged 65 and over. For further discussion of blood dyscrasias see Appendix A (2).

Blood dyscrasias: Mechanisms of myelotoxicity and concentrationeffect relationships

The possibility of an immunological basis for the blood dyscrasias produced by pyrazolones has been considered and seems to be likely for aminopyrine. Whilst phenylbutazone and oxyphenbutazone have similarities in their structures to aminopyrine, an immunological mechanism seems unlikely in view of the moderate or long median treatment days, respectively, associated with most cases of agranulocytosis and aplastic anaemia linked to phenylbutazone and oxyphenbutazone myelotoxicities.

In an in vitro system, using human myeloid progenitor cells, Firkin and Moore (1976), showed that phenylbutazone interfered with the proliferation of colonies harvested from the bone marrow of three phenylbutazone-induced aplasia subjects, one idiopathic aplasia subject and eight healthy subjects. Selectively increased sensitivity of the aplastic anaemia subjects did not occur but, in all three groups, the formation of colonies and clusters was dependent on phenylbutazone concentration; reductions were inapparent at concentrations of 10 and $20 \mu \mathrm{g} / \mathrm{mL}$, but proliferation was decreased at 30, 40, 50 and $100 \mu \mathrm{g} / \mathrm{mL}$.

Smith et al. (1977) demonstrated inhibition of proliferation of marrow granulocyte-monocyte precursors by phenylbutazone, oxyphenbutazone and $\gamma$-hydroxyphenylbutazone in marrow cells from normal subjects and three patients who had recovered from aplastic anaemia. Moreover, this inhibition was again concentration-dependent over the range $3.08-308 \mu \mathrm{g} / \mathrm{mL}$. The marrow cells from recovered aplastic anaemia patients were somewhat more sensitive to phenylbutazone but not to oxyphenbutazone. Overall, it would seem that evidence for a greater sensitivity of cells from aplastic anaemia patients is not convincing.

In discussing the mechanism(s) of phenylbutazone-associated myelotoxicity, Yunis and Gross (1975) and Chaplin (1986) reported no effect on in vitro proliferation of mouse myeloid cell colonies or human marrow colonies in agar. In contrast, chloramphenicol and thiamphencol produced marked inhibition of proliferation; these antibacterial drugs exerted concentration-dependent direct toxic effects on marrow cells (Yunis and Gross, 1975). Both phenylbutazone and oxyphenbutazone inhibited in vitro DNA synthesis in human bone marrow cells from normal human subjects (Dewse and Potter, 1975). Concentrations of $10-200 \mu \mathrm{g} / \mathrm{mL}$ produced concentration-dependent inhibition in two subjects and profound inhibition at all concentrations in one subject. These concentrations are considerably higher than the free phenylbutazone concentrations in human serum (up to $99 \%$ of total concentration being protein bound). On the other hand, exposure time was short $(1 \mathrm{~h})$. It is of interest that, in this study, the addition of $20 \%$ serum to the medium abolished or markedly reduced the inhibitory action of phenylbutazone, demonstrating the likely free drug concentration dependency of this action of phenylbutazone. Similar findings were reported for oxyphenbutazone.

The possibility of rare individual sensitivity, even to low phenylbutazone/oxyphenbutazone concentrations, cannot be excluded. As always, it is impossible to prove a negative. However, the available human in vivo data relate solely to rare sensitivity to full therapeutic doses. Even if the sensitivity, as well as being very rare, were to occur at low concentrations, there will always have to be a limiting lower concentration and period of exposure, below which this type of toxicity will not occur. The general finding of medium (several weeks) to long (several months) median daily exposures of most subjects prior to the occurrence of agranulocytosis and aplastic anaemia, respectively, points towards a highly likely dependence on daily dose and duration of exposure.

Sperling (1969) commented that all serious side-effects of phenylbutazone were greater up to 1954 , when relatively large doses, up to $1600 \mathrm{mg}$ daily, were often administered. There is some evidence to indicate that dyscrasias are dose related. Ramsey and Golde (1976) noted that, 'although the mechanism of phenylbutazone-induced hematologic toxicity is not known, there is some evidence that it is dose related. The incidence of leukopenia, thrombocytopenia, anaemia, and aplastic anaemia in the earliest clinical trials using up to $1.6 \mathrm{~g}$ daily was considerably higher than later trials using lower dosages'. Leyland et al. (1974) reflected on the possibility that an increased propensity for side-effects of 
phenylbutazone might be related to increased exposure, as a consequence of reduced rate of metabolism in individuals.

\section{Carcinogenicity}

Phenylbutazone has been described as possibly associated with the development of acute leukaemia (O'Brien and Bagby, 1985). Most cases were from 1960 to 1965 . However, a direct causal link has not been established and epidemiological studies have not confirmed any links. For further discussion see Appendix A (3).

\section{Risk analysis}

This review makes no attempt to undertake a full risk analysis. This will be appropriate when further data are available to form the basis of a quantitative risk evaluation. Based on available data, the European Food Safety Authority (EFSA) and the European Medicines Agency (EMA) provided a risk analysis, after acceptance of this review article (EFSA/EMA, 2013).The following account provides a preliminary risk analysis on the basis of some but not all of the currently available data.

\section{Ban on use of phenylbutazone in food producing species}

Banning phenylbutazone in food producing species comprises application of the precautionary principle. The standard for setting Maximum Residue Limits (MRLs) is that it should be possible to consume a meal containing residues of drugs and metabolites every day for a whole lifetime, with negligible risk to human health. The rationale of this a priori regulatory approach dedicated to chronic food safety risk assessment does not hold for the a posteriori risk assessment of a possible acute risk associated with the ingestion of a banned substance that consumers are not exposed to daily for their entire lives. In other words, conclusions of the risk leading to the ban on phenylbutazone in food producing animals in European Union (EU) must be placed in the perspective of a low, illegal and erratic exposure of consumers.

\section{Horse meat consumption in the European Union}

In the EU, horses and other Equidae are considered by law to be food producing species; Table 4 indicates the number of slaughtered horses in European countries and the corresponding tonnages. In 2011, the leading five countries in terms of slaughtered horses were Italy $(62,237)$, Romania $(53,000)$, Poland $(41,729)$, Spain $(41,729)$ and UK $(20,000)$, but horse meat consumption does not mirror these numbers, especially for the UK, which exports almost all its horse meat. The EU horse meat consumption in 2008

\section{Table 4}

Horses slaughtered in Europe (heads and tonnes in 2011, 10 first countries) (FAOSTAT). ${ }^{\mathrm{a}}$

\begin{tabular}{rlcl}
\hline & Country & Tonnes/year & Horses slaughtered \\
\hline 1 & Italy & 16,527 & 62,237 \\
2 & Poland & 13,300 & 41,729 \\
3 & Romania & 9540 & 53,000 \\
4 & Spain & 6500 & 32,000 \\
5 & France & 4500 & 15,500 \\
6 & Germany & 3118 & 11,812 \\
7 & UK & 3080 & 20,000 \\
8 & Greece & 2700 & 15,000 \\
9 & Ireland & 2250 & 9000 \\
10 & Belgium & 2115 & 9613 \\
\hline
\end{tabular}

a See: http://faostat.fao.org/site/569/DesktopDefault.aspx?PageID=569\#ancor (accessed 8 April 2013). was 96,000 tons, comprising $0.2 \%$ of total meat consumption, giving an average yearly meat consumption of $\sim 170 \mathrm{~g}$ per inhabitant.

Horse meat consumption is variable between countries and between regions within countries (as in Italy), but reliable data on regional differences are difficult to obtain. The two countries with the largest horse meat consumption are Italy (45,000 tons in 2008 , corresponding to $1 \%$ of the total domestic Italian meat consumption) and France (20,000 tons in 2008, comprising $0.4 \%$ of the total domestic meat consumption). In France, horse meat consumption in 2011 was 17,967 tonnes, giving a nominal average meat consumption per capita of $\sim 300 \mathrm{~g}$. However, it should be noted that the concept of an average consumer for horse meat is inappropriate, in terms of risk analysis, because horse meat is actually consumed by only a fraction of the population. In France, only $16.7 \%$ of homes actually bought horse meat in 2011; therefore, the average consumption per home was $2.7 \mathrm{~kg}$ for 2011 and consumption up to $10 \mathrm{~kg}$ per year is to be expected in the heaviest consumers. Any risk analysis should take into account this uneven distribution of horse meat consumption within each EU country.

\section{Concentrations of phenylbutazone and oxyphenbutazone in horse meat: Experimental data}

In a small equine study, we recorded lower muscle than plasma concentrations of phenylbutazone (Lees et al., 1987; Table 2). Beyond $24 \mathrm{~h}$ after dosing, concentrations were in parts per billion and decreasing. Considering that plasma concentration of phenylbutazone is an appropriate biomarker of muscle concentration (see above), and considering a plasma-to-muscle ratio of 10:1$30: 1$, prediction of muscle concentrations consistent with the actual observations can be undertaken, allowing proposals for various exposure scenarios.

\section{Detection and quantitation of phenylbutazone in horse muscle and processed meats: Survey data}

In food-producing animals in the EU, for several prohibited or unauthorised substances, Minimum Required Performance Limits (MRPL) for the analytical methods have been specified. ${ }^{2}$ MRPLs are 'the minimum content of an analyte in a sample, which at least has to be detected and confirmed'. There is no MPRL in the EU for phenylbutazone. Therefore, negative results are difficult to interpret and may be a source of confusion between countries having different analytical capabilities. In the UK, the level of quantification (LOQ) for phenylbutazone is $0.6 \mu \mathrm{g} / \mathrm{kg}$ and the level of detection (LOD) is $\sim 0.4 \mu \mathrm{g} / \mathrm{kg}$. A sample is considered to be positive (traces) for phenylbutazone in the range $0.4-0.6 \mu \mathrm{g} / \mathrm{kg}$ and positive (quantified) $>0.6 \mu \mathrm{g} / \mathrm{kg}$.

In the UK, $\sim 8000$ horses are slaughtered annually for human consumption $^{3}$ and, as indicated above, the great majority is destined for export to other EU countries. In 2011, 1/68 (1.9\%) of kidney samples taken at abattoirs tested positive for phenylbutazone. ${ }^{3}$ For the 4 year period from 2008 to 2011, the number of samples positive for phenylbutazone in equine kidney samples was $8 / 224$ (3.6\%). In 2012,8426 horses were slaughtered for human consumption and, of these, 145 were tested for phenylbutazone; 5/145 (3.44\%) tested positive. If this is multiplied for all slaughtered animals, this gives an estimated incidence rate of 290 for the 8426 horses slaughtered. Whilst this is a low percentage, any number exceeding zero is too high to be acceptable.

More recently, the UK Foods Standards Agency (FSA) reported that 206 equine carcasses had been tested for phenylbutazone

\footnotetext{
${ }^{2}$ See: http://ec.europa.eu/food/food/chemicalsafety/residues/docs/requirements_ non_eu.pdf

${ }^{3}$ See: http://www.vmd.defra.gov.uk/VRC/pdf/PositionPaper_Phenylbutazone.pdf.
} 
between 30th January and 7th February 2013; eight (3.9\%) tested positive and six of these positive samples had been sent to France, where they may have entered the food chain. ${ }^{4}$ These data have been necessarily flagged as a cause for concern, since phenylbutazone is banned for use in food producing species in all EU countries, as discussed above. The range and mean of actual concentrations detected are not provided; however, this is highly relevant, since it might or might not relieve concerns on residues, noting moreover that muscle concentrations will normally be significantly lower than those in kidney. Under a new system, introduced on 30th January 2013 , the FSA has introduced testing of all horse carcases for phenylbutazone in the UK, and only those testing negative will be released from the slaughterhouse. Test results become available within $\sim 48 \mathrm{~h}$.

There is particular concern when or if animal carcasses testing positive have been transported to European countries and destined for entry into the human food chain, or before the results of testing have become known. In this regard, it seems likely that it will be necessary to review the equine passport system in the UK and similar controls in other countries. The UK Veterinary Residues Committee position paper $^{5}$ indicates that some veterinary surgeons are prescribing phenylbutazone for horses without checking the passports or ensuring that the animals are subsequently out of the food chain. Moreover, phenylbutazone residues have also been found in horses that have changed owners prior to going to slaughter, and whose passports do not indicate that they have been signed out of the food chain. Even when a horse has been exported, the FSA informs the European Commission in the event of a positive sample. An alert is issued to the Member States to instigate withdrawal of the product from the market if necessary. A combined UK Veterinary Medicines Directorate (VMD) and Department for Environment, Food and Rural Affairs (Defra) guidance for veterinary surgeons and horse owners is available on the VMD/Defra website. ${ }^{6}$

Based on National Residue Control Plans in the EU, an April 2013 report (EFSA/EMA, 2013) for 19 member states indicated that of 2386 horse tissue samples, 37 (1.55\%) were positive for phenylbutazone. The highest detection rate was for kidney samples (2.8\%); the highest concentration measured was $1900 \mu \mathrm{g} / \mathrm{kg}$ but the median kidney concentration was much lower, $4.0 \mu \mathrm{g} / \mathrm{kg}$. Of 672 muscle samples one $(0.1 \%)$ was positive for phenylbutazone, at a concentration of $19.2 \mu \mathrm{g} / \mathrm{kg}$.

\section{Intake of phenylbutazone from horse meat and processed meat products}

Calculations, based on actual or estimated data, can be undertaken regarding the possible consumption of phenylbutazone in horse meat.

(1) After an intravenous high dose of phenylbutazone $(8.8 \mathrm{mg} /$ $\mathrm{kg}$ ), average plasma concentrations in four horses were $1.235,0.16,0.057$ and $0.034 \mu \mathrm{g} / \mathrm{mL}$, respectively, at 24,48 , 72 and 96 h (Orszag, 2008); assuming a plasma-to-muscle ratio of 10:1 and considering a typical meat intake of $300 \mathrm{~g}$ per day (the EU food basket), the ingested amount of phenylbutazone would be $\sim 37,4.8,1.71$ and $1.03 \mu \mathrm{g}$ in total at these times. This comprises a much lower exposure than with the recommended human therapeutic dose $(2-6 \mathrm{mg} /$ $\mathrm{kg}$ or $140,000-450,000 \mu \mathrm{g}$ in total for a $70 \mathrm{~kg}$ person).

\footnotetext{
4 See: http://www.food.gov.uk/news-updates/news/2013/feb/bute-carcasses results\#.UW9hc7FOJjo.

${ }^{5}$ See: http://www.vmd.defra.gov.uk/VRC/pdf/PositionPaper_Phenylbutazone.pdf.

${ }^{6}$ See: www.vmd.defra.gov.uk.
}

(2) Taking the weight of one commercial burger as $100 \mathrm{~g}$ and, assuming that, at one sitting, an individual consumes two burgers containing $100 \%$ horse meat, and also assuming the horse was killed 6-12 h after dosing, the intake of phenylbutazone (plus a similar or lesser amount of oxyphenbutazone) from the data in Table 2 would be of the order of $40 \mu \mathrm{g}$ for a $40 \mathrm{~kg}$ child, corresponding to a phenylbutazone 'dose' of $1.0 \mu \mathrm{g} / \mathrm{kg}$ bodyweight. This is vastly less than the recommended daily dose of phenylbutazone for human use.

(3) Considering the worst case scenario that slaughtered horses received a maximum recommended phenylbutazone dose $24 \mathrm{~h}$ before processing, the annual exposure for a heavy horse meat consumer (10 kg per year) cannot exceed $1200 \mu \mathrm{g}$, which is about $1 / 400$ of a single daily therapeutic human dose. These examples of low 'intake doses' can be regarded as 'worst case', since most horses are unlikely to be slaughtered within $24 \mathrm{~h}$ of dosing, and also considering that derived products might contain less than $100 \%$ horse meat. On 15th February 2013, the FSA reported that, of 2501 beef products tested, 29 were positive for horse DNA; of these 29 positive samples, all tested negative for phenylbutazone.

In summary, these worst case intake examples involve consumption of amounts of phenylbutazone (and its metabolites) that are well below any possible pharmacological or general toxicological effects, as defined above. There remains, however the main concern, namely the risk of blood dyscrasias. In veterinary medicine, chloramphenicol was banned from food producing animals because of a rare but potentially fatal risk of aplastic anaemia. However, for chloramphenicol it was shown that the reaction was idiosyncratic, not dose-related, thus explaining the association between the administration of topical ocular chloramphenicol and aplastic anaemia in man (Laporte et al., 1998). Hence, very small amounts of chloramphenicol can constitute a potential hazard, when present in foodstuffs.

In contrast to chloramphenicol, the balance of evidence is that aplastic anaemia caused by phenylbutazone is not idiosyncratic, but is rather dose-related and, hence, in the body, concentrationdependent. Moreover, the incidence of life-threatening dyscrasias is low, of the order of 1 in 20,000-100,000 for therapeutically exposed human subjects (2-6 $\mathrm{mg} / \mathrm{kg}$ daily, usually for several weeks or commonly longer). Finally, there is the factor of lack of detectable concentrations of phenylbutazone, using analytical assays with an ability to detect concentrations in kidney of $\sim 0.5-5 \mu \mathrm{g} /$ $\mathrm{kg}$ in up to $95 \%$ of horse samples. Consequently, the likelihood of observing a blood dyscrasia caused by a phenylbutazone residue arising from an illegal use of the drug in an EU consumer is negligible, particularly when the management options (e.g. EU ban on phenylbutazone, passports for horses) are made to operate effectively.

\section{European Union equine regulations to guarantee the safety of horse meat}

To allow for the fact that horses can be reared for purposes other than food production (e.g. sport, racing, pleasure), management procedures exist to debar slaughtered horses from entering the food chain. Central to these procedures is the equine passport; Equidae in all EU countries must be accompanied by a passport during their movements. The passport has a section in which treatments with certain veterinary medicines must be recorded. In addition, all medicinal treatments must also be recorded in records kept on the farm in the UK (where the horse is not a food producing animal, but can potentially enter the EU food chain following exportation) 
The VMD has produced Veterinary Medicines Guidance Notes (Document VMGN16), ${ }^{7}$ which describes the circumstances and procedures relating to the use of all medicines in horses and how the passport system is intended to operate. Whilst phenylbutazone is not banned from equine use, it cannot be used in any food producing animal. Moreover, 'passports must be signed at part II of section IX to indicate that the animal is not intended for human consumption'. This is a legal responsibility under the UK Horse Passport regulations on the website. ${ }^{8}$

In all EU states, some veterinary products are authorised for use in food producing horses and these products have a MRL and associated withdrawal period; in the EU, certain substances with no EU MRL for Equidae, but nevertheless essential for their treatment, can be used, including use in food producing horses (Regulation 1950/ 2006). ${ }^{9}$ Moreover, treated animals can enter the food chain if the treatment is documented in the equine passport and a default withdrawal period of 6 months is observed before slaughter. An updated list of these substances, almost 100 in number, has been released (Commission regulation (EU) no. 122/2013). ${ }^{9}$ Phenylbutazone is not included in this list, so that any horse in the EU treated with phenylbutazone must be irreversibly excluded from the food chain

\section{Conclusions}

Phenylbutazone was extensively used in human medicine but subsequently withdrawn due its severe side-effects that include blood dyscrasias. In veterinary medicine, phenylbutazone is a major non-steroidal anti-inflammatory drug that is used for treatment in horses; several EU States will allow its use, but only for horses excluded from the food chain. According to EU legislation, treatment of horses with phenylbutazone must be recorded in their passport and the presence of phenylbutazone residues in horse meat is therefore the result of its illegal and probably infrequent use.

In all investigated species, phenylbutazone concentrations in muscle are least 10 times lower than the corresponding plasma concentrations; after an IV high dose of phenylbutazone $(8.8 \mathrm{mg} /$ $\mathrm{kg}$ ), the possible ingested amount of phenylbutazone would be $\sim 40 \mu \mathrm{g}$ in total for a consumer eating $300 \mathrm{~g}$ horse meat in one sitting, i.e. less than $1 / 1000$ of a phenylbutazone therapeutic dose in man.

The main concern for the safety of phenylbutazone residues relates to the occurrence of aplastic anaemia in humans; however, this side-effect was reported in humans only at a low rate of $\sim 1$ in 20,000-100,000 and without clear evidence against its dosedependency. Uncertainties regarding the genotoxicity and carcinogenicity of phenylbutazone were an issue when the EU attempted to determine MRLs, i.e. food concentrations to which a consumer can be potentially exposed daily for an entire life without harmful consequences; this a priori regulatory approach, designed in relation to chronic food safety risk assessment, does not hold for the a posteriori risk assessment of a possible acute risk associated with the very unlikely ingestion by humans of phenylbutazone in horse meat as a banned substance.

\section{Conflict of interest statement}

Neither of the authors of this paper has a conflict of interest that could inappropriately influence or bias the content of the paper.

\footnotetext{
${ }^{7}$ See: www.vmd.defra.gov.uk/public/vmr_vmgn.aspx (accessed 8 April 2013).

8 See: www.vmd.defra.gov.uk.

9 See: http://eur-lex.europa.eu/LexUriServ/LexUriServ.do?uri=OJ:L:2013:042: 0001:0017:EN:PDF.
}

\section{Appendix A. Supplementary data}

Supplementary data associated with this article can be found, in the online version, at http://dx.doi.org/10.1016/j.tvjl.2013.04.019.

\section{References}

Aarbakke, J., 1978. Clinical pharmacokinetics of phenylbutazone. Clinical pharmacokinetics 3, 369-380.

Aarbakke, J., Bakke, O.M., Milde, E.J., Davies, D.S., 1977. Disposition and oxidative metabolism of phenylbutazone in man. European Journal of Clinical Pharmacology 11, 359-366.

Authié, E., Garcia, P., Popot, M.A., Toutain, P.L., Doucet, M.Y., 2010. Effect of an endurance-like exercise on the disposition and detection time of phenylbutazone and dexamethasone in the horse: Application to medication control. Equine Veterinary Journal 42, 240-247.

Awang, D.V., Vincent, A., Matsui, F., 1973. Pattern of phenylbutazone degradation Journal of Pharmaceutical Sciences 62, 1673-1676.

Bakke, O.M., Draffan, G.H., Davies, D.S., 1974. The metabolism of phenylbutazone in the rat. Xenobiotica 4, 237-254.

Bellward, G.D., Morgan, R.G., Beaulne, V.H. Mitchell, A.G. 1972 . Effect of phenylbutazone breakdown products on drug metabolism assay. Journal of Pharmacy and Pharmacology 24, 338-339.

Bottiger, L.E., 1977. Phenylbutazone, oxyphenbutazone and aplastic anaemia. British Medical Journal 2, 265.

Bottiger, L.E., Westerholm, B., 1973. Drug-induced blood dyscrasias in Sweden. British Medical Journal 3, 339-343.

Brideau, C., Van Staden, C., Chan, C.C., 2001. In vitro effects of cyclooxygenase inhibitors in whole blood of horses, dogs, and cats. American Journal of Veterinary Research 62, 1755-1760.

Burns, J.J., Rose, R.K., Chenkin, T., Goldman, A., Schulert, A., Brodie, B.B., 1953. The physiological disposition of phenylbutazone (butazolidin) in man and a method for its estimation in biological material. Journal of Pharmacology and Experimental Therapeutics 109, 346-357.

Cameron, A., Eisen, A.A., Niranjan, L.M., 1966. Aplastic anaemia due to phenylbutazone. Postgraduate Medical Journal 42, 49-51.

Chaplin, S., 1986. Bone marrow depression due to mianserin, phenylbutazone, oxyphenbutazone, and chloramphenicol - Part I. Adverse Drug Reactions and Acute Poisoning Reviews 5, 97-136.

Chay, S., Woods, W.E., Nugent, T.E., Weckman, T., Houston, T., Sprinkle, F., Blake, J.W., Tobin, T., Soma, L.R., Yocum, J., et al., 1984. Population distributions of phenylbutazone and oxyphenbutazone after oral and i.v. dosing in horses. Journal of Veterinary Pharmacology and Therapeutics 7, 265-276.

Collins, L.G., Tyler, D.E., 1984. Phenylbutazone toxicosis in the horse: A clinical study. Journal of American Veterinary Medical Association 184, 699-703.

Davies, D.S., Thorgeirsson, S.S., 1971. Mechanism of hepatic drug oxidation and its relationship to individual differences in rates of oxidation in man. Annals of the New York Academy of Sciences 179, 411-420.

Dayton, P.G., Israili, Z.H., Perel, J.M., 1973. Influence of binding on drug metabolism and distribution. Annals of the New York Academy of Sciences 226, 172-194.

Delbeke, F.T., Vynckier, L., Debackere, M., 1993. The disposition of suxibuzone in the horse. Journal of Veterinary Pharmacology and Therapeutics 16, 283-290.

Dewse, C.D., Potter, C.G., 1975. Inhibitory effect of phenylbutazone and oxyphenbutazone on DNA synthesis in normal human bone marrow cells in vitro. Journal of Pharmacy and Pharmacology 27, 523-526.

Dieterle, W., Faigle, J.W., Fruh, F., Mory, H., Theoblad, W., Alt, K.O., Richter, W.J., 1976. Metabolism of phenylbutazone in man. Arzneimittel-Forschung 26, 572 577.

EFSA/EMA, 2013. Joint statement of EFSA and EMA on the presence of residues of phenylbutazone in horse meat. European Food Safety Authority Journal 11, 3190 (45 pages).

Faich, G.A., 1987. Risks and indications of phenylbutazone: Another look. Pharmacotherapy 7, 25-27.

Firkin, F.C., Moore, M.A.S., 1976. Atypical phenylbutazone sensitivity of marrow colony forming units in phenylbutazone-induced aplastic anemia. In: Aplastic Anaemia. Proceedings of the First International Symposium on Aplastic Anemia 3-4 September 1976, Kyoto, Japan. University Park Press, Baltimore, USA, pp. 335-342.

Fowler, P.D., 1967. Marrow toxicity of the pyrazoles. Annals of Rheumatic Diseases 26, 344-345.

Gabel, A.A., Tobin, T., Ray, R.S., Maylin, G.A., 1977. Phenylbutazone in horses Review. Journal of Equine Medicine and Surgery 1, 221-225.

Gerring, E.L., Lees, P., Taylor, J.B., 1981. Pharmacokinetics of phenylbutazone and its metabolites in the horse. Equine Veterinary Journal 13, 152-157.

Gierse, J.K., Staten, N.R., Casperson, G.F., Koboldt, C.M., Trigg, J.S., Reitz, B.A., Pierce, J.L., Seibert, K., 2002. Cloning, expression, and selective inhibition of canine cyclooxygenase- 1 and cyclooxygenase-2. Veterinary Therapeutics 3, 270-280.

Giri, A.K., Mukhopadhyay, A., 1998. Mutagenicity assay in Salmonella and in vivo sister chromatid exchange in bone marrow cells of mice for four pyrazolone derivatives. Mutation Research 420, 15-25.

Hale, G.S., De Gruchy, G.C., 1960. Aplastic anaemia following the administration of phenylbutazone. Medical Journal of Australia 47, 449-453. 
Hazleton, L.W., Tusing, T.W., Holland, E.G., 1953. Acute and chronic toxicity of butazolidin. Journal of Pharmacology and Experimental Therapeutics 109, 387392.

Higgins, A.J., Lees, P., Taylor, J.B., 1984. Influence of phenylbutazone on eicosanoid levels in equine acute inflammatory exudate. Cornell Veterinarian 74, 198-207.

Horwitz, D., Thorgeirsson, S.S., Mitchell, J.R., 1977. The influence of allopurinol and size of dose on the metabolism of phenylbutazone in patients with gout. European Journal of Clinical Pharmacology 12, 133-136.

Inman, W.H., 1977. Study of fatal bone marrow depression with special reference to phenylbutazone and oxyphenbutazone. British Medical Journal ii, 1500-1505.

Jaraiz, M.V., Rodriguez, C., San Andres, M.D., Gonzalez, F., San Andres, M.I., 1999 Disposition and tolerance of suxibuzone in horses. Equine Veterinary Journal 31, 411-416.

Kari, F., Bucher, J., Haseman, J., Eustis, S., Huff, J., 1995. Long-term exposure to the antiinflammatory agent phenylbutazone induces kidney tumors in rats and liver-tumors in mice. Japanese Journal of Cancer Research 86, 252-263.

Kirkland, D., Fowler, P., 2010. Further analysis of Ames-negative rodent carcinogens that are only genotoxic in mammalian cells in vitro at concentrations exceeding $1 \mathrm{mM}$, including retesting of compounds of concern. Mutagenesis 25, 539-553.

Kujubu, D.A., Fletcher, B.S., Varnum, B.C., Lim, R.W., Herschman, H.R., 1991. TIS10, phorbol ester tumor promoter-inducible mRNA from Swiss 3T3 cells, encodes a novel prostaglandin synthase/cyclooxygenase homologue. Journal of Biological Chemistry 266, 12866-12872.

Lander, H., Bonnin, J.M., 1962. Pernicious anaemia associated with aplastic anaemia following phenylbutazone therapy. Medical Journal of Australia 49, 297-300.

Laporte, J.R., Vidal, X., Ballarin, E., Ibanez, L., 1998. Possible association between ocular chloramphenicol and aplastic anaemia - The absolute risk is very low. British Journal of Clinical Pharmacology 46, 181-184.

Lees, P., Higgins, A.J., 1985. Clinical pharmacology and therapeutic uses of nonsteroidal anti-inflammatory drugs in the horse. Equine Veterinary Journal 17 , 83-96.

Lees, P., Higgins, A.J., 1986. Effects of a phenylbutazone paste in ponies: Model of acute nonimmune inflammation. American Journal of Veterinary Research 47, 2359-2363.

Lees, P., Higgins, A.J., 1987. Physiological, biochemical and haematological effects on horses of a phenylbutazone paste. Veterinary Record 121, 56-60.

Lees, P., Creed, R.F., Gerring, E.E., Gould, P.W., Humphreys, D.J., Maitho, T.E., Michell, A.R., Taylor, J.B., 1983. Biochemical and haematological effects of phenylbutazone in horses. Equine Veterinary Journal 15, 158-167.

Lees, P., Higgins, A.J., Mawhinney, I.C., Reid, D.S., 1986a. Absorption of phenylbutazone from a paste formulation administered orally to the horse. Research in Veterinary Science 41, 200-206.

Lees, P., Taylor, J.B., Higgins, A.J., Sharma, S.C., 1986b. Phenylbutazone and oxyphenbutazone distribution into tissue fluids in the horse. Journal of Veterinary Pharmacology and Therapeutics 9, 204-212.

Lees, P., Taylor, J.B., Maitho, T.E., Millar, J.D., Higgins, A.J., 1987. Metabolism, excretion, pharmacokinetics and tissue residues of phenylbutazone in the horse. Cornell Veterinarian 77, 192-211.

Lees, P., Ayliffe, T., Maitho, T.E., Taylor, J.B., 1988. Pharmacokinetics, metabolism and excretion of phenylbutazone in cattle following intravenous, intramuscular and oral administration. Research in Veterinary Science 44, 57-67.

Lees, P., Landoni, M.F., Giraudel, J., Toutain, P.L., 2004. Pharmacodynamics and pharmacokinetics of nonsteroidal anti-inflammatory drugs in species of veterinary interest. Journal of Veterinary Pharmacology and Therapeutics 27, 479-490.

Lewis, R.J., 2004. Sax's Dangerous Properties of Industrial Materials, 11th Ed. Wiley and Sons, New Jersey, USA.

Leyland, M.J., Cunningham, J.L., Delamore, I.W., Evans, D.A., 1974. A pharmacokinetic study of phenylbutazone-associated hypoplastic anaemia. British Journal of Haematology 28, 142-143.

Liang, I.E., Estes, K.E., Bird, S.B., Brush, D.E., Aaron, C.K., Boyer, E.W., 2004. Acute phenylbutazone toxicity: A toxicokinetic analysis. Journal of Toxicology: Clinical Toxicology 42, 745-746.

MacAllister, C.G., 1983. Effects of toxic doses of phenylbutazone in ponies. American Journal of Veterinary Research 44, 2277-2279.

MacKay, R.J., French, T.W., Nguyen, H.T., Mayhew, I.G., 1983. Effects of large doses of phenylbutazone administration to horses. American Journal of Veterinary Research 44, 774-780.

Maekawa, A., Onodera, H., Tanigawa, H., Furuta, K., Kanno, J., Matsuoka, C., Ogiu, T. Hayashi, Y., 1987. Long-term studies on carcinogenicity and promoting effect of phenylbutazone in DONRYU rats. Journal of the National Cancer Institute 79, 577-584.

Maitho, T.E., Lees, P., Taylor, J.B., 1986. Absorption and pharmacokinetics of phenylbutazone in Welsh Mountain ponies. Journal of Veterinary Pharmacology and Therapeutics 9, 26-39.

Mauer, E.F., 1955. The toxic effects of phenylbutazone (butazolidin); Review of the literature and report of the twenty-third death following its use. New England Journal of Medicine 253, 404-410.

McCarthy, D.D., Chalmers, T.M., 1964. Hematological complications of phenylbutazone therapy: Review of the literature and report of two cases. Canadian Medical Association Journal 90, 1061-1067.

McConnico, R.S., Morgan, T.W., Williams, C.C., Hubert, J.D., Moore, R.M., 2008 Pathophysiologic effects of phenylbutazone on the right dorsal colon in horses. American Journal of Veterinary Research 69, 1496-1505.
Mortelmans, K., Haworth, S., Lawlor, T., Speck, W., Tainer, B., Zeiger, E., 1986. Salmonella mutagenicity tests. 2. Results from the testing of 270 chemicals. Environmental Mutagenesis 8, 1-119.

Newton, T.A., Rose, S.R., 1991. Poisoning with equine phenylbutazone in a racetrack worker. Annals of Emergency Medicine 20, 204-207.

O'Brien, W.M., Bagby, G.F., 1985. Rare adverse reactions to nonsteroidal antiinflammatory drugs. Journal of Rheumatology 12, 347-353.

Orszag, A., 2008. Cinétiques d'élimination plasmatique et urinaire de la phénylbutazone chez le cheval dans le cadre de la lutte anti-dopage: Application au contrôle des médications. Thèse d'Exercice, Docteur Médecine Vétérinaire. Ecole Nationale Vétérinaire de Toulouse, Université Paul Sabatier de Toulouse, Toulouse, Française, 70 pp.

Ramsey, R., Golde, D.W., 1976. Aplastic anemia from veterinary phenylbutazone. Journal of the American Medical Association 236, 1049.

Rowland, M., Tozer, T.N., 2009. Clinical Pharmacokinetics and Pharmacodynamics: Concepts and Applications, Fourth Ed. Lippincott William and Wilkins, Philadelphia, Pennsylvania, USA, 864 pp.

Schmid, R.W., 1970. Über das hydrolysegleichgewicht von phenylbutazon (Butazolidin ${ }^{\circledR}$ ). Helvetica Chimica Acta 53, 2239-2251.

Singh, G., 1998. Recent considerations in nonsteroidal anti-inflammatory drug gastropathy. American Journal of Medicine 105, 31S-38S

Singh, G., Triadafilopoulos, G., 1999. Epidemiology of NSAID induced gastrointestinal complications. Journal of Rheumatology 56, 18-24.

Smith, C.S., Chinn, S., Watts, R.W.E., 1977. The sensitivity of human bone marrow granulocyte/monocyte precursor cells to phenylbutazone, oxyphenbutazone and gamma-hydroxyphenylbutazone in vitro, with observations on the bone marrow colony formation in phenylbutazone-induced granulocytopoenia. Biochemical Pharmacology 26, 847-852.

Smith, P.B., Caldwell, J., Smith, R.L., Horner, M.W., Moss, M.S., 1987. The bioavailability of phenylbutazone in the horse. Xenobiotica 17, 435-443.

Snow, D.H., Bogan, J.A., Douglas, T.A., Thompson, H., 1979. Phenylbutazone toxicity in ponies. Veterinary Record $105,26-30$

Snow, D.H., Douglas, T.A., Thompson, H., Parkins, J.J., Holmes, P.H., 1981. Phenylbutazone toxicosis in Equidae: A biochemical and pathophysiological study. American Journal of Veterinary Research 42, 1754-1759.

Soma, L.R., Uboh, C.E., Maylin, G.M., 2011. The use of phenylbutazone in the horse. Journal of Veterinary Pharmacology and Therapeutics 35, 1-12.

Sperling, I.L., 1969. Adverse reactions with long-term use of phenylbutazone and oxyphenbutazone. Lancet ii, 535-537.

Stephens Jr., C.A., Yeoman, E.E., Holbrook, W.P., Hill, D.F., Goodin, W.L., 1952 Benefits and toxicity of phenylbutazone (butazolidin) in rheumatoid arthritis. Journal of the American Medical Association 150, 1084-1086.

Stevenson, A.C., Bedford, J., Hill, A.G., Hill, H.F., 1971. Chromosomal studies in patients taking phenylbutazone. Annals of Rheumatic Diseases 30, 487-500.

Taylor, J.B., Lees, P., Gerring, E.L., 1981. Analysis of phenylbutazone and its metabolites by high performance liquid chromatography. Equine Veterinary Journal 13, 201-203.

Taylor, J.B., Walland, A., Lees, P., Gerring, E.L., Maitho, T.E., Millar, J.D., 1983. Biochemical and haematological effects of a revised dosage schedule of phenylbutazone in horses. Veterinary Record 112, 599-602.

Tobin, T., Chay, S., Kamerling, S., Woods, W.E., Weckman, T.J., Blake, J.W., Lees, P., 1986. Phenylbutazone in the horse: A review. Journal of Veterinary Pharmacology and Therapeutics 9, 1-25.

Toutain, P.L., Alvinerie, M., Ruckebusch, Y., 1980a. Pharmacocinetique et residus de la phenylbutazone chez la vache. Annales de Recherches Vétérinaires 11, 391397

Toutain, P.L., Alvinerie, M., Ruckebusch, Y., 1980b. Residue profile of phenylbutazone in the rabbit. A comparative evaluation by tissue kinetics prior to and post mortem. Journal of Veterinary Pharmacology and Therapeutics 3, 255-259.

Toutain, P.L., Autefage, A., Legrand, C., Alvinerie, M., 1994. Plasma concentrations and therapeutic efficacy of phenylbutazone and flunixin meglumine in the horse: Pharmacokinetic/pharmacodynamic modelling. Journal of Veterinary Pharmacology and Therapeutics 17, 459-469.

Traub, J.L., Gallina, A.M., Grant, B.D., Reed, S.M., Gavin, P.R., Paulsen, L.M., 1983. Phenylbutazone toxicosis in the foal. American Journal of Veterinary Research 44, 1410-1418.

Triggs, E.J., Whyatt, P.L., Eckert, G., 1977. Bioavailability evaluation of an entericcoated phenylbutazone formulation, and cross-over comparison with a sugarcoated product. Medical Journal of Australia 2, 830-833.

Vane, J.R., 1971. Inhibition of prostaglandin synthesis as a mechanism of action for aspirin-like drugs. Nature New Biology 231, 232-235.

Von Rechenberg, H.K., 1962. Phenylbutazone, Butazolidin, Second Ed. Edward Arnold, London, UK, $197 \mathrm{pp}$.

Whittaker, J.A., Price Evans, D.A., 1970. Genetic control of phenylbutazone metabolism in man. British Medical Journal 4, 323-328.

Yu, T.F., Burns, J.J., Paton, B.C., Gutman, A.B., Brodie, B.B., 1958. Phenylbutazone metabolites: Antirheumatic, sodium-retaining and uricosuric effects in man Journal of Pharmacology and Experimental Therapeutics 123, 63-69.

Yunis, A.A., Gross, M.A., 1975. Drug-induced inhibition of myeloid colony growth Protective effect of colony-stimulating factor. Journal of Laboratory and Clinical Medicine 86, 499-504. 